\title{
DIVERSIFIKASI MANGGA OFF GRADE MENJADI SELAI DAN DODOL
}

\author{
Cahyuni Novia $^{1)}$, Syaiful ${ }^{2)}$, Deny Utomo ${ }^{3)}$ \\ ${ }^{1}$ Sekolah Tinggi Teknologi Nurul Jadid Probolinggo \\ email : vhie771108@gmail.com \\ ${ }^{2}$ Sekolah Tinggi Teknologi Nurul Jadid Probolinggo \\ email : syaiful@gmail.com \\ ${ }^{3}$ Fakultas Pertanian, Universitas Yudharta Pasuruan \\ email : denyut369@gmail.com
}

\begin{abstract}
Karanganyar village is a good mango producing area of excellent quality and off grade. The lack of knowledge about the processing of mango off grade diversification leads to lower selling prices. Training diversified manufacture of processed mango off grade into jams and dodol is appropriate for the conditions of rural communities Karanganyar. Manufacture of butter and mango dodol off grade is focused on the handling and processing of raw materials are accurate and correct, so that the resulting product quality. The method used is lectures and applications making of jam and mango dodol off grade and their packaging. Achievement on the training of making jam and mango dodol off grade is a partner all participants can make jam and dodol well and their packaging.

Keywords: mango, jam, dodol
\end{abstract}

\section{PENDAHULUAN}

Desa Karanganyar adalah sebuah desa yang terletak di Kecamatan Paiton Kabupaten Probolinggo Propinsi Jawa Timur. Desa Karanganyar merupakan salah satu desa penghasil mangga arumanis dan manalagi terbesar di Kecamatan Paiton Kabupaten Probolinggo. Potensi tanaman mangga arumanis dan manalagi yang ada di Desa Karanganyar ini masih sangat bagus, produksi tanaman mangga arumanis dan manalagi untuk setiap kali panen dalam satu pohon rata-rata menghasilkan 5-7 kuintal, sedangkan jumlah pohon mangga arumanis dan manalagi yang terdapat di desa ini berjumlah 350 pohon dan menghasilkan produksi sebesar 175-245 ton. Produksi mangga kualitas off grade baik jenis arumanis atau manalagi sekali panen sekitar $10 \%$ (17,5-24,5 ton) untuk 350 pohon di desa Karanganyar. Mangga off grade adalah buah mangga yang ukurannnya kecil dan bentuknya tidak normal (Dewandari et al., 2009).

Mangga merupakan buah yang dapat tumnuh di daerah tropis (Jahurul et al., 2015). Menurut Muchiri et al. (2012), buah mangga menempati peringkat 2 sebagai tanaman tropis setelah pisang. Buah mangga merupakan sumber penting dari mikronutrien, vitamin dan phytochemical lainnya. Selain itu, buah-buahan mangga memberikan energi, diet serat, karbohidrat, protein, lemak dan senyawa fenolik (Tharanathan et al., 2006).

Buah mangga mengandung vitamin $\mathrm{C}$ yang cukup tinggi dan dapat dikonsumsi dalam bentuk segar maupun sebagai olahan (Deptan, 2009). Nilai kandungan gizi mangga secara umum per $100 \mathrm{~g}$ terdiri dari energi $272 \mathrm{~kJ}$ (65 kcal), karbohidrat $17 \mathrm{~g}$, gula $14,8 \mathrm{~g}$, diet serat $1,8 \mathrm{~g}$, lemak $0,27 \mathrm{~g}$, protein $0,51 \mathrm{~g}$, vitamin A equiv. 38 $\mathrm{mg}$, beta-karoten $445 \mathrm{mg}$, thiamine (Vitamin B1) $0.058 \mathrm{mg}$, riboflavin (Vitamin B2) 0,057 mg, niacin (Vitamin B3) $0,584 \mathrm{mg}$, asam pantotenat (Vitamin B5) 0,160 mg, vitamin B6 0,134 mg, folat (Vitamin B9) $14 \mathrm{mg}$, vitamin C $27,7 \mathrm{mg}$, kalsium $10 \mathrm{mg}$, besi $0,13 \mathrm{mg}$, magnesium $9 \mathrm{mg}$, fosfor $11 \mathrm{mg}$, kalium $156 \mathrm{mg}$, dan seng 0,04 mg (Anonymous, 2012).

Banyaknya kandungan gizi yang terdapat pada mangga sangat bermanfaat bagi kesehatan bagi manusia antara lain; kandungan zat besinya sangat baik bagi ibu hamil dan penderita anemia, dapat melancarkan pencernaan, menurunkan tekanan darah, menurunkan kolesterol, menyehatkan serta menambah daya tahan tubuh, memperkecil risiko terkena pembentukan batu ginjal, meningkatkan kehidupan seks seseorang, pencegah kanker, peluruh urine, penyegar, 
penambah napsu makan, pencahar ringan, peluruh dahak dan antioksidan, baik untuk kesehatan mata, mulut, dan tenggorokan. Beta-karoten (dan vitamin C) pada buah mangga juga tergolong antioksidan, senyawa yang dapat memberikan perlindungan terhadap kanker karena dapat menetralkan radikal bebas (Anonymous, 2013).

Mangga kualitas off grade yang selalu dihasilkan setiap panen masih mempunyai nilai ekonomi tinggi jika dijual dalam bentuk olahan. Hancuran daging buah mangga kaya akan gizi, mengandung berbagai vitamin dan mineral. Bubur buah mangga atau puree adalah produk setengah jadi yang dapat diolah lebih lanjut menjadi aneka produk makanan dan minuman (Setyadjit et al., 2005). Mangga kualitas off grade dapat dipergunakan sebagai bahan baku untuk selai dan dodol (Antarlina et al., 2005).

Masyarakat di Desa Karanganyar hanya memanfaatkan mangga arumanis dan manalagi kualitas off grade untuk dijual kepasar dalam bentuk segar (belum diolah) dengan harga yang murah, bahkan jika panen raya banyak yang terbuang percuma karena tidak ada yang mau membeli. Hal ini terjadi karena ketidak pahaman masayarakat setempat tentang jenis produk lain yang dapat dihasilkan dari bahan baku mangga arumanis dan manalagi off grade, masyarakat juga belum memahami teknologi sederhana apa yang dapat diaplikasikan pada mangga yang mereka miliki. Mereka beranggapan bahwa mangga hanya bisa jual dalam bentuk segar (belum diolah). Padahal hanya dengan sentuhan teknologi yang sederhana mangga kualitas off grade dapat menjadi produk olahan yang bernilai tinggi dibandingkan dengan menjual dalam bentuk segar. Salah satunya adalah mengolah mangga arumanis atau manalagi menjadi selai dan dodol.

Dodol menurut SNI 01-2986-1992 merupakan makanan semi basah yang pembuatannya dari tepung beras ketan, santan kelapa dan gula dengan atau tanpa tambahan bahan makanan lain yang diijinkan. Hasilnya merupakan adonan berbentuk padatan yang cukup elastis berwarna coklat muda sampai coklat tua (Anonymous, 2013).

Pelatihan pembuatan produk selai dan dodol, tim pelaksana lebih memfokuskan pada penanganan bahan baku dan cara mengatur tingkat penggunaan api pada proses pemasakan. Pada proses pemasakan harus menggunakan api kecil dan lebih sering di aduk-aduk untuk mendapatkan tingkat kekentalan yang diinginkan. Kondisi tersebut dianggap penting untuk dijelaskan, karena hasil survei tim pelaksana menunjukkan bahwa masyarakat desa Karanganyar sama sekali belum mengetahui cara pembuatan selai dan dodol mangga off grade dengan baik dan benar.

\section{METODE PENELITIAN}

\section{Rancangan kegiatan}

Lingkup kegiatan ini dilaksanakan mulai dari bulan Januari hingga Juli 2015, yaitu bermula dari persiapan dalam tim pelaksana, mempersiapkan lokasi dan mitra kerja, pelaksanaan praktek pembuatan produk dan peninjauan keberlanjutan kegiatan.

\section{Khalayak Sasaran}

Pemilihan mitra kerja dilihat dari keseriusan, keaktifan dan keberlanjutan organisasi yang terdapat di Desa Karanganyar. Penentuan mitra kerja ini dianggap sangat penting karena menjadi salah satu indikator keberhasilan kegiatan. Subyek yang disurvei adalah petani mangga dan Ibu-ibu PKK. Hasil survei yang meliputi wawancara dan observasi mengarah pada Ibu PKK dan petani mangga sebagai mitra kerja yang sesuai.

Kondisi ini diperkuat karena organisasi ini dianggap aktif, organisasi yang terarah dan anggotanya juga sebagai istri-istri dari petani mangga dan berinteraksi dengan baik dalam kelompok tani. Hal ini diharapkan agar keberlanjutannya adalah dapat mentransfer ketrampilan yang didapatkan saat kegiatan pada kelompok yang lain.

\section{Bahan dan alat}

Bahan selai meliputi, mangga off grade kualitas afkir, tepung beras, tepung tapioka, air, garam, bawang putih,gula, dan margarine. Bahan dodol meliputi, mangga off grade, santan, gula, natrium metabisulfit, garam, margarine, dan tepung ketan.

Blender, pemarut kelapa, sealer, dandang, kompor, pisau, talenan, sutil, bak penampungan bahan, wajan, sendok pengaduk, nampan cetakan, sepet, dan plastik kemasan.

\section{Desain dan kinerja alat}

Mesin dan peralatan yang digunakan pada kegiatan ini sederhana dan lebih pada teknologi tepat guna yang dirancang sesuai dengan kondisi pedesaan, yaitu hemat energi, mudah digunakan, 
efesien dalam produktivitas, mudah dipindahpindahkan dan mudah dalam perawatannya. Pada kegiatan ini menggunakan mesin dan peralatan produksi hingga pengemasan.

\section{Teknik pengumpulan data dan analisis data}

Pengumpulan data dilakukan dengan melakukan wawancara pada pengurus PKK dan masyarakat. Pengumpulan data ini dimaksudkan untuk mengetahui status sosial, pendidikan dan motivasi mitra kerja dalam kegiatan IbM yang dilaksanakan agar target luaran dapat tercapai.

Target luaran dinilai pada saat pelaksanaan kegiatan praktek pembuatan selai dan dodol mangga off grade dan pemantauan keberlanjutan kegiatan.

\section{HASIL DAN PEMBAHASAN}

Hasil pelaksanaan kegiatan Pengabdian kepada masyarakat melibatkan dua mitra. Mitra kerja yang ikut dalam kegiatan pelatihan pembuatan produksi dan pengemasan adalah 20 orang dengan distribusi pendidikan 8 orang SMU, 8 orang SMP dan 4 orang SD. Secara umum, pendidikan mitra kerja cukup baik dan data yang ditemui menunjukkan bahwa tidak ada seorang pun dari peserta yang pernah mengetahui cara pembuatan selai dan dodol mangga off grade.

Rendahnya pengetahuan pasca panen mangga off grade mitra kerja dengan berlimpahnya bahan baku mangga off grade di desa Karanganyar merupakan fenomena yang menarik perhatian tim kerja untuk melatih dan mentransfer pengetahuan pembuatan selai dan dodol mangga off grade. Tabel 1 memperlihatkan jumlah mitra kerja yang pernah membuat selai dan dodol mangga off grade sebelum kegiatan IbM dilaksanakan

Tabel 1. Mitra kerja yang pernah membuat selai dan dodol mangga sebelum kegiatan $\mathrm{IbM}$

\begin{tabular}{lll}
\multicolumn{2}{c}{ Selai } & Dodol \\
\hline Pernah & 0 & 0 \\
Belum pernah & 20 & 20 \\
Jumlah & 20 & 20 \\
\hline
\end{tabular}

Tabel 2. Produk yang dihasilkan menarik, dapat dikembangkan dan bernilai jual

\begin{tabular}{lrc}
\hline & Selai & Dodol \\
\hline Ya & 20 & 16 \\
Tidak & 0 & 4 \\
Jumlah & 20 & 20 \\
\hline
\end{tabular}

Tabel 3. Bahan baku mudah diperoleh dan cara pembuatan produk mudah dibuat sendiri

\begin{tabular}{lcc}
\hline & Selai & Dodol \\
\hline Ya & 20 & 20 \\
Tidak & 0 & 0 \\
Jumlah & 20 & 20 \\
\hline
\end{tabular}

Mitra kerja yang berjumlah 20 orang belum pernah membuat selai dan dodol mangga off grade (Tabel 1). Setelah melaksanakan kegiatan, ternyata $100 \%$ mitra kerja dapat membuat produk selai dan dodol mangga off grade dengan baik yaitu secara fisik dan rasa selai dan dodol menarik sehingga dapat dikembangkan sebagai produk pasca panen mangga off grade yang memberikan alternatif selain dijual dalam bentuk segar (Tabel 2). Kondisi produk akan lebih menarik dan ketahanan produk meningkat dengan dilakukan pengolahan dan pengemasan yang benar.

Peralatan pengemasan yang dimiliki mitra kerja menjadi modal penting dalam pengembangan produk dan peningkatan nilai jual selai dan dodol mangga off grade. Dasar dalam pengembangan produk yaitu bahan dasar yaitu mangga off grade sangat mudah didapatkan di desa Karanganyar. Produk selai dan dodol mangga off grade juga relatif mudah di buat oleh mitra kerja pada saat pelatihan produksi (Tabel 3) dan saat peninjauan keberlanjutan kegiatan. Saat membuat selai dan dodol mangga off grade, tim pelaksana memberikan alternatif dan penjelasan yang mendasar serta sederhana. Penjelasan tersebut berkenaan dengan mitra kerja yang akan mengkonsumsi produk yang dibuat.

\section{KESIMPULAN}

Dua tahapan kegiatan pengabdian kepada masyarakat yang telah dilakukan dapat disimpulkan bahwa:

1. Seluruh mitra kerja dapat membuat selai dan dodol mangga off grade serta melakukan pengemasan dengan baik.

2. Produk selai dan dodol mangga off grade yang dihasilkan pada pelatihan produksi menarik dan dapat dikembangkan.

3. Bahan dasar pembuatan produk selai dan dodol, yaitu mangga off grade yang mudah didapatkan di desa Karanganyar 


\section{DAFTAR PUSTAKA}

Anonymous. 2012. Kandungan Nutrisi Gizi dan Vitamin Dalam Buah Mangga. http://antama.blogspot.com/2012/05 /kandungannutrisi-gizi-dan-vitamin_3607.html. Diakses tanggal 6 April 2014.

Anonymous. 2013. Manfaat buah mangga untuk kesehatan.http://manfaattumbuhanbuah.blog spot.com/2013/11/manfaat-buah-manggatuntuk-kesehatan.html. Diakses tanggal 6 April 2014

Antarlina, S. S. \& Umar, S. 2012. Teknologi pengolahan komoditas unggulan mendukung pengembangan agroindustri di lahan lebak.

Deptan. 2009. Standar operasional prosedur pengolahan mangga. Direktorat Jenderal Pengolahan Dan Pemasaran Hasil Pertanian. Jakarta

Dewandari, K. T., Mulyawanti, I. \& Amiarsi, D. 2009. Pembekuan cepat puree mangga arumanis dan karakteristiknya selama penyimpanan. Jurnal Pasca Panen 6 (1): 2733.
Jahurul, M. H. A., Zaidul, I. S. M., Ghafoor, K., Al-Juhaimi, F. Y., Nyam, K. L., Norulaini, N. A. N., Sahena, F. \& Omar, A. M. 2015. Mango (Mangifera indica L.) by-products and their valuable components: a review. Food Chemistry $183: 173-180$.

Muchiri, D. R., Mahungu, S. M., \& Gituanja, S. N. 2012. Studies on Mango (Mangifera indica, L.) kernel fat of some kenyan varieties in Meru. Journal of the American Oil Chemist's Society 89: 1567-1575.

Setyadjit, Widaningrum \& Sulusi, P. 2005. Agroindustri puree mangga : mengatasi panen berlimpah. Warta Penelitian dan Pengembangan Pertanian 27(5): 4-5.

Tharanathan, R. N., Yashoda, H. M., \& Prabha, T. N. 2006. Mango (Mangifera indica L.), The king of fruits - A review. Food Reviews International 22: 95-123.

Utomo, D., Wahyuni, R. \& Novia, C. 2014. Diversifikasi produk olahan apel manalagi kualitas afkir menjadi selai dan dodol. Jurnal Agrika 8 (2):211-218 